\title{
TRANSVALORIZĂRI HIPERTEXTUALE ÎN PALIMPSESTUL NARATIV SARA DE ŞTEFAN AGOPIAN
}

\section{ANDREEA ANA-MARIA BARB}

\section{Universitatea din București}

\begin{abstract}
In this paper, I will examine the novel Sara, published by Stefan Agopian in 1987. The novel is a rewriting of the Book of Tobit, from the Old Testament, and is preceded by another novel written by the prose writer on the same biblical theme, entitled Tobit. I will approach the work from the perspective

the overvaluation that certain notions suffer, in the transition from the Bible to its narrative Agopian. Transvalorization is a literary phenomenon discussed by G. Genette in his study, Palimpsestes (1982), but my method is not entirely faithful to the narrator.
\end{abstract}

Keywords: novel, Agopian, biblical theme, Tobit

În lucrarea de față, voi examina romanul Sara, publicat de Ștefan Agopian în 1987.

Romanul este o rescriere a Cărții lui Tobit, din Vechiul Testament, și e precedat de un alt roman scris de prozator pe aceeași temă biblică, intitulat Tobit. Voi aborda opera din perspectiva transvalorizării pe care o suferă anumite noțiuni, în trecerea de la Biblie la narațiunea lui Agopian. Transvalorizarea este un fenomen literar discutat de G. Genette în studiul său, Palimpsestes (1982), însă metoda mea nu îi este în totalitate fidelă naratologului.

Un palimpsest este o narațiune (numită hipertext) ce se află într-o puternică legătură cu o altă narațiune, care o precedă (hipotext) și din care preia elemente definitorii. Genette teoretizează fenomenele care marchează operele cu punct de plecare în texte anterioare. Transvalorizarea e unul din aceste fenomene și reprezintă o transformare axiologică („orice intervenție la nivelul valorii implicit sau explicit atribuite unor acțiuni: 
anume, succesiunea de acțiuni, atitudini și trăiri ce constituie un personaj" '). În această direcție, transvalorizarea este definită „ca o dublă mișcare de devalorizare și (contra) valorizare, aplicate aceluiași personaj"'.

Naratologul examinează efectele transvalorizării exclusiv asupra personajelor. În studiul meu, însă, mă voi focaliza pe un alt tip de transvalorizare, neadus în discuție de Genette: acela al conceptelor, ideilor și valorilor „importate”. Dincolo de personaje, în Sara remarcăm o serie de elemente biblice ce merită examinate din această prismă, precum: divinitatea, iubirea, demonii, moartea, morala, viața de apoi, destinul, conștiința, liberul arbitru etc. Toate acestea au semnificații stabile în paradigma veterotestamentară, iar Ștefan Agopian le resemantizează în romanele sale, în cheie livrescă postmodernistă. În capitolele ce urmează, ele vor face parte din obiectul nostru de studiu.

\section{CONSTRÎNGERILE ISTORIEI HIPOTEXTUALE: SARA}

Povestea biblică din Cartea lui Tobit, după cum știm, decurge astfel: Tobit tatăl, orbit de o pasăre, își trimite fiul (cu acelaşi nume) la unchiul său, pentru a recupera niște talanți. Acel unchi are o fiică Sara, care s-a măritat de 7 ori, însă de fiecare dată demonul Asmodeus i-a omorât soțul în noaptea nunții, căci era îndrăgostit de ea. Tobit fiul e însoțit pe drum de îngerul Rafail, deghizat în călător, iar Tobit se căsătorește cu Sara și scapă de demon cu ajutorul lui Rafail.

În romanul lui Agopian, acțiunea se mută în Sibiul lui 1703. Tobit are 25 de ani, iar Sara 18. Ea este înfiată, dar s-a născut într-o familie din Spania, care era convinsă că Sara este posedată de un demon încă de la vîrsta de 4-5 ani. Nu este, însă, adusă în discuție nicio parte a istoriei ei biblice ce privește logodnele multiple sau demonul Asmodeus. În fond, Agopian reinterpretează tema demonului îndrăgostit care, în romanul lui, nu mai e văzut ca o entitate exterioară personajului, ci ca o realitate interioară.

La începutul romanului, Sara primește o scrisoare de la Tobit, prin care el își anunță venirea la Sibiu. Pînă în acel moment, cei doi sau familiile lor

\footnotetext{
1. "any operation of an axiological nature bearing on the value that is implicitly assigned to an action or group of actions: namely, the sequence of actions, attitudes, and feelings that constituted a "character»" - Genette, G., 1997, Palimpsests: Literature in the Second Degree, trad. din fr. de Newman, Ch., trad. proprie din engl., University of Nebraska Press, Nebraska, p. 343

2. "a double movement of devaluation and (counter)valuation bearing on the same characters"Ibid., p. 367
} 
nu s-au întîlnit niciodată. Cu toate acestea, scrisoarea prevestea o realitate viitoare deja cunoscută. Cînd tatăl Sarei îi înmînează fetei scrisoarea, replica ei este următoarea: „Am citit-o, spuse Sara. Tobit va veni în casa ta și eu mă voi îndrăgosti de el’3. Reacția ei este una marcată de resemnare, nu de entuziasm (vom vedea de ce).

Acel „mă voi indrăgosti” este desemnificat. Scrisoarea intră în categoria documentelor în care soarta personajelor biblice este înscrisă. Tobit și Sara vor fi împreună, (re)confirmînd scenariul biblic. Ba mai mult, ea va rămîne grea cu el, în pofida faptului că tînăra murise, deși istoria veterotestamentară nu prevedea niciuna dintre aceste variațiuni. Dar pentru Ștefan Agopian, ficțiunea este domeniul posibilului, chiar și atunci cînd destinele personajelor sunt pre-scrise. Deviza acestei proze este, de altfel, „ne putem imagina”, cu subtextul că totul este posibil, chiar și atunci cînd știm cum au stat, de fapt, lucrurile, sau mai ales atunci cînd nu știm ce s-a întîmplat.

Pe de altă parte, destinul pre-scris al Sarei nu îi poate dirija și sentimentele. Conștiința structurantă a acestui univers ficțional îi permite protagonistei să se abată afectiv de la coordonatele biblice. Sara nu este îndrăgostită de Tobit, ci de Kinder. Sora ei vitregă, la rîndul ei, era îndrăgostită de Tobit. Neputîndu-l avea pe Tobit, pentru că destinul sau Cartea nu i-l rezervase ei, Clara decide să se logodească cu Kinder, deși nu manifestă niciun interes afectiv pentru el. După ce o face pe Sara să sufere așa cum suferă și ea, sora vitregă rupe logodna cu Kinder și se duce la mănăstire - dovedind că intenția ei de a se căsători cu Kinder nu a existat niciodată.

După cum vedem, transferul unui personaj dintr-un text în altul implică perpetuarea unor elemente-cheie din construcția identitară a acelui personaj. Căsătoria dintre Tobit și Sara devine doar o convenție preluată din Vechiul Testament, dar care trebuie respectată indiferent cît de mult se devalorizează. Personajele importate nu se pot sustrage coordonatelor care le definesc, indiferent cît de multe variațiuni permite narațiunea în care au fost transferate („Niciodată n-o să fie cum vrem noi” ${ }^{4}$ ). Așa cum remarcă Monica Spiridon, „destinul personajelor rămîne neatins de presiunea conjuncturii, ascultînd mai curînd de o providență livrescă" ${ }^{5}$.
3. Ibid., p. 46
4. Ibid., p. 257
5. Spiridon, M., 2012, „Agopian, Ștefan”, în Simion, E. (coord.), Dicționarul literaturii române, ed. cit., p. 28 
Într-o anumită măsură, personajele sunt ca niște păpuși de ventriloc, a căror mișcări sunt controlate de altcineva:

"[Tobit și Sara] porniră, ea mișcîndu-se țeapăn, ca o păpuşă căreia cineva, nu știm cine, $i$-a trezit la viață numai picioarele, nu și restul, iar el la fel de țeapăn."6

În consecință, libertatea actantului este limitată în raport cu textul de origine, însă autorul găsește o modalitate ingenioasă de a relaxa transferul, permițînd personajelor să se abată afectiv de la scenariu. Autorul reușește să creeze un simulacru al libertății de gîndire și de afecte în ceea ce privește protagoniștii.

\section{UN DUMNEZEU ATROFIAT, ÎN REGRESIE MORALĂ}

În Sibiul anului 1703 al lui Agopian, lui Dumnezeu îi lipsesc majoritatea atributelor considerate definitorii pentru o divinitate. Isși pierde omnisciența, sau chiar renunță la ea de bunăvoie, din apatie. Rămîne fără orice fărîmă de interes pentru ce se întîmplă cu omenirea, s-a retras și s-a dezis de „atribuțiile” lui, în manieră deistă. Aducînd în discuție dorința anumitor cetățeni de a-l vedea pe primarul Sibiului ucis, naratorul apreciază că

„Cel-care-stă-deasupra-lucrurilor pare de la un timp indiferent și mohorît si prea puțin interesat de cele ce se întîmplă, dar mai ales de cum se întîmplă lucrurile pe care, demult, atunci cînd a făcut totul, le-a hotărît."

Intr-o chestiune atît de importantă cum este viaţa unui om, acest Dumnezeu este impasibil. Am putea specula că avem de-a face cu o divinitate amorală, însă nu se rezumă la o postură neutră, pasivă față de răul uman, ci dezvoltă tendințe sadice:

„Dacă îl vor omorî pe Schuller el n-ar avea nimic împotrivă dacă $i$-ar omorîs și pe alţii. (...) Dacă tot sînt puşi pe omorît, continuă el, nu vede nici un motiv ca omorîtul să nu ia măcar proporțiile unei decimări. ${ }^{\text {'s }}$

Raționamentul funcționează pe principiul conform căruia dacă nu îl atinge un rău „mic”, izolat, nu îl atinge nici unul de proporții, însă măcar celălalt e suficient de vizibil încît să stîrnească interesul. În orice caz, replica este grăitoare pentru nivelul de detașare cu care acest Dumnezeu este construit, căci gustul pentru genocid derivă tot din apatie.

Pe lîngă simțul moralității, realizarea livrescă a divinității pierde

6. Agopian, S., 2006, Sara, ed. cit., p. 153

7. Ibid., p. 55

8. Ibid. 
și atributele ilimitării. Dumnezeul biblic este infinit, atemporal, indestructibil. Între timp, despre entitatea căreia i-a fost desemnată denumirea de „Dumnezeu” în acest univers ficțional, aflăm că

"Ce va fi după aceea el nu știe și nici nu-și poate închipui. Timpul ce i-a fost hărăzit și în care e viu și vorbește nu ajunge pînă acolo, dincolo de întîmplările toamnei și începutul iernii acestui an, anul care ne va urma, anul 1704, este un an gol și tăcut și morții care vor popula viitorul nu-i spun nimic."

Observăm că această divinitate este înscrisă în timp, limitată de coordonatele și de curgerea lui. Nu cunoaște viitorul și n-are nici măcar imaginația să îl speculeze. I-a fost „hărăzită” o perioadă în care i se permite să trăiască. Deducem, astfel, că în universul ficțional există ceva sau cineva care se plasează deasupra lui Dumnezeu - conștiința structurantă a labirintului romanesc, Autorul, care are putere inclusiv asupra divinității. În acești parametri ficționali, pînă și morții au acces la o cunoaștere mai extensivă decît divinitatea.

\section{REVALORIZAREAARHANGHELULUI RAFAIL. O UMANITATE CONTRADICTORIE}

De regulă, când un arhanghel își face apariția printre oameni, în Vechiul Testament, el își ascunde adevărata natură. I̦și camuflează angelicul, adoptă posturi și obiceiuri umane, pentru a nu ieși în evidență și a nu fi deconspirat. E trimis printre oameni cu cîte o misiune salutară divină, însă ajutorul lui este camuflat sub forma bunăvoinței unui trecător ca oricare altul.

Arhanghelul Rafail al lui Agopian adoptă alte strategii. Protejarea naturii angelice de văzul lumii nu reprezintă o prioritate. Din contră, în loc să perpetueze misterul, el își etalează natura celestă: levitează, are aripile la vedere, i se scurge lumină din buricele degetelor.

De asemenea, în loc să păstreze din grația unui înger, din maturitatea și înțelepciunea specifică, el se dovedește a fi stîngaci, uneori infantil, deranjant chiar. Are o multitudine de gesturi, atitudini și expresii prin care cade în ridicol, este aruncat în derizoriu:

"[cineva] îl auzi pe Rafail, foșnetul pe care îl face un bărbat plutind în aer, un foșnet pedicular și us,or grețos" ${ }^{10}$;

„Fața lui copilăroasă și zbîrcită se destinse o clipă (...). S, Schiopătînd,

9. Ibid., p. 55-56

10. Ibid., p. 15 
Rafail se apropie."11

Observăm că arhanghelul dă, totuși, dovadă de umanitate. El resimte senzații eminamente umane, cum ar fi oboseala sau foamea:

"-Mi-e foame.

Sara zîmbi spre Rafail și spuse:

- Ingerilor nu le este nici foame, nici somn, nici frig. Nouă da! (...)

- Mi-e foame si somn. "12

Dincolo de condiționările organice, acest Rafail experimentează rușine, stînjeneală. În momentul în care stă de vorbă cu Sara și Tobit într-un hambar, cei doi fiind goi (într-o scenă care reproduce imaginea cuplului adamic), Rafail simte nevoia să se explice, să se scuze chiar, că el nu posedă organul masculin, din „cauza” naturii lui angelice:

"[Sara] surîse și îi privi pe cei doi, pe Tobit gol și cu mădularul atîrnîndu-i vinețiu intre picioare și pe Rafail cu hainele lui strălucitoare și între picioarele lui neatîrnînd nimic.

- Noi, spuse Rafail, stînjenit parcă, nu sîntem bărbat sau femeie.

- Știu asta, spuse Sara (...) și spunîndu-i aceasta, Rafail se fistîci de tot." ${ }^{13}$

\section{DEMONI CU VOCAȚIE ARTISTICĂ VS. DEMONI INTERIORI}

În romanul lui Agopian, demonul Sarei dispare, alături de toate evenimentele pe care le declanșează. El nu se regăsește niciunde în roman. Blestemul Sarei este transformat într-o presupusă posedare demonică din copilărie. Simptomatica este vagă și concludentă numai pentru mama Sarei: tenul palid, plăcerea ocazională a copilei de a zbiera și tendința ei către izbucniri agresive - nimic ieșit din comun, de altfel, pentru un copil de cinci ani, necizelat, cu un potențial temperament coleric. Aceste aspecte sunt suficiente, însă, pentru ca mama să fie convinsă că Sara are nevoie de o serie de tratamente inumane punitive, violente sau deprivative, prin care copila să fie exorcizată.

Romanul din 1987 conține, în schimb, cîteva realizări alternative ale figurii demonice, considerate de Eugen Negrici "demoni simpatici” ${ }^{14}$. Una dintre cele mai colorate reprezentări se concretizează în make-up artistul consilierului Gross:

„Un demon din cei știuţi pașnici și doritori de discuții savante se oglindi

11. Ibid., p. 41

12. Ibid., pp. $199-202$

13. Ibid., pp. $203-204$

14. Negrici, E., 1999, „Prefață”, în Agopian, S,., Tache de catifea, ed. cit., p. 5 
lîngă el, îi zîmbi [consilierului Gross]. (...) Apoi demonul, profitînd de lumina plăcută ce cobora prin ferestrele înalte ale odăii, aduse o pensulă scurtă și cîteva borcane de porțelan, pline cu vopsele și, indeminnatic și repede, desfăcu borcanele, fluieră o melodie încă necunoscută orașului Sibiu, și îl fardă pe domnul consilier Gross întinerindu-l cu mai multe zeci de ani.

(...) Fruntea demonului se încreți o clipă, păru că se gîndește la cele spuse de domnul consilier Gross, apoi zîmbi iar, tîmp de astă dată și privind buzele roșii ale bătrînului domn." 15

Acest demon apare din neant, mișcat de dorința lui Gross de a arăta mai tînăr, articulată în timp ce se privea în oglindă. Apariția nu are loc ca urmare a unei invocații sau din cauza vreunui declanșator, ci din proprie inițiativă demoniacă. Observăm aici un demon resemantizat total, cu un acut simț estetic, un interes pentru cromatica machiajelor, cu empatie chiar, față de Gross și de dorința lui de a se vedea întinerit. Această entitate face parte „din cei știuți pașnici””' din firescul universului ficțional în care ne regăsim. Nu în ultimul rînd, este o apariție prietenoasă, jovială, zîmbindu-i consilierului Gross cînd îl întîlnește.

O variantă mai puțin inofensivă a demoniei apare în preajma baronului Spurck, sub forma unui omuleț capabil să se strecoare invaziv în interioritatea umană și să îl împingă pe om către moarte:

„- Orice creier, îi va spune [baronul] cu cîteva zile înainte să se sinucidă lui Tobit, este ca o burtă preaîncăpătoare și flască și în această burtă plutește ful nostru adormit și visind și știind. (...) Și aș mai putea spune, a spus in continuare Spurck, că de acolo de unde e, acest fiu uriass și viermic ne batjocorește și ne impinge către moarte.

Baronul Casimir Spurck s-a spinzurat a doua zi după aceste cuvinte spuse și ascultate și Tovit l-a văzut (...) pe acel fu dolofan și umed și roșietic, dînd tîrcoale si bucurîndu-se și știind că intr-o zi totul va fi la fel. Și coborînd la picioarele tatălui său, i-a cuprins picioarele cu mîinile lui spurcate și gura lui băloasă a sărutat acele picioare."17

Deși această entitate de dimensiuni reduse nu este introdusă în mod explicit în categoria prezențelor demonice, aceasta prezintă o serie de trăsături convenționale care îi justifică apartenența: este „roșieticc, dă tîrcoale omului și-l ispitește. Observăm, totuși, că demonul minion nu

\footnotetext{
15. Agopian, S,., 2006, Sara, ed. cit., p. 59

16. Ibidem, p. 59

17. Ibidem, pp. $94-95$
} 
invadează sufletul sau trupul, pur și simplu, cum obișnuiește să o facă în narațiunile biblice, ci creierul uman. Ba mai mult de-atît, el este "fiul dolofan" al celui pe care îl acaparează, omul fiind "tatăl său”.

Autorul construiește un demon care nu mai poate fi catalogat drept sursa exterioară ce ne împinge la autodistrugere, ci este chiar produsul minții umane, al propriului creier. Demonii cu adevărat periculoși, care ne pot devora, sunt cei pe care îi construim noi înșine în interiorul nostru - sunt ,fii" propriei noastre minți.

\section{UN PERSONAJ CARE NU-ȘI APART,INE: BARONUL SPURCK}

Baronul Casimir Spurck face parte din categoria personajelor care nu au beneficiat de o existență anterioară romanului Sara, apariția lui constituind un element de noutate. Este genul de personaj marcat de o acută luciditate în ceea ce îi privește statutul ficțional și limitările care vin cu el. Existența îi este dominată de apatie, cu ocazionale impulsuri de revoltă, protest, ce nasc din frustrarea incapacității de a avea un control real asupra propriei vieți.

Identitatea romanescă a baronului este dominată de conștiința faptului că el urmează să moară în curînd (nu știe nimeni exact cînd înseamnă acest „curînd”). Multiple personaje îi aduc aminte de iremediabilul sfîrșit care-l așteaptă, deși el este perfect conștient de ce i se va întîmpla.

Curios este faptul că moartea lui „trebuie” să aibă loc prin spînzurare. Și nu oricum - căci nu este o crimă - ci are loc din proprie inițiativă. Toate secvențele care anunță moartea baronului o ilustrează ca pe un suicid. Într-o anumită măsură, putem înțelege de ce. Complet dezinteresat de viață, Spurck ajunge să aibă fantezii elaborate în ceea ce-i privește sfîrșitul - el își fetișizează propria moarte. Ne-ar fi ușor să deducem că și-o dorește, dacă nu ar apărea o serie de elemente contradictorii la nivelul narațiunii.

Ruxandra Ivăncescu punctează că baronul ,stie că într-o bună zi se va sinucide - deși o face parte datorită destinului său prescris de «istoria» cărții, parte, firește, din plictiseală"18.

Convențional, sinuciderea este înțeleasă drept moartea pe ți-o decizi singur. Dar suicidul lui pare deja stabilit, pre-scris, pînă în punctul în care nu l-ar mai putea eluda nici dacă ar vrea - astfel, decizia nu îi mai aparține. Sinuciderea este, la rîndul ei, resemantizată aici, nemaireprezentînd un fapt determinat exclusiv de voința persoanei decidente și condus la înfăptuire de către ea, ci un alt dat exterior căruia personajul nu i se poate

18. Ivăncescu, R., 2000, Ștefan Agopian: monografie, ed. Aula, București, p. 37 
sustrage nici dacă ar vrea.

Baronul are obiceiul de a omorî păsări. O face ori de cîte ori are ocazia și simte o satisfacție interioară din actul în sine. În contextul în care Spurck nu simte că deține controlul asupra propriei vieți și/sau a propriei morți, dorința de a omorî păsări poate naște ca un mecanism prin care personajul reușește să facă față realității ficționale care-l vizează. Omorîtul păsărilor îi oferă un grad de control asupra suflului unei vietăți, simte că ține o viață în mîini și că decizia de a o întrerupe (sau nu) îi aparține, în evident contrast cu lipsa de control pe care o resimte asupra lui însuși.

La un moment dat, baronul ucide un papagal, care i se adresează înainte să-i fie frînt gîtul, implorîndu-l: „Nu mă ucide, stăpîne!”19. Cîteva minute mai tîrziu însă, Casimir „o luă la fugă, auzi zgomotul batjocoritor al papagalilor în urma lui și ei îl anunțau (...) că în curînd va muri" ${ }^{20}$. Din această secvență transpare legătura care se creează, în conștiința personajului, între viitoarea lui moarte și omorîtul păsărilor.

$\mathrm{Nu}$ în cele din urmă, baronul Spurck are un moment în care problematizează el însuși sentimentul că nu-și aparține:

" «într-adevăr, cu cît ne aparținem mai mult nouă, cu atît ne aparținem mai puțin», cuvîntul die Abgeschiedenheit, adică "izolare», revenind des in discuție, poate "abdicare de la ceea ce aparține timpului și locului», das Nichst. Nu știm. Adică nu putem ști adevărul, dar ni-l putem închipui în diverse chipuri și moduri: "lipsa voinței proprii de a ne regăsi» și care, acest fel de a privi lucrurile, nu ne aparține, cum nu ne aparține cu adevărat nimic din ceea ce facem, vremea și locul." ${ }^{11}$

\section{ÎN LOC DE CONCLUZII}

Dimensiunea hipertextuală a romanului Sara constituie prilej de problematizare, relativizare și resemantizare a noțiunilor, elementelor și figurilor cu care am făcut cunoștință în hipotext(e). Figura care domină prin excelență corpusul biblic, Dumnezeu, trece printr-o atrofiere a compasului moral, care aduce cu sine pierderea majorității atributelor considerate convențional divine. Arhanghelul Rafail își etalează atributele angelice, în acte de indiscreție totalmente nonhipotextuale, însă dobîndește, simultan, o serie de atribute omenești - iar absența altora dintre ele îl stînjenește. Registrul demonic se scindează în entități simpatice și entități distructive,

19. Agopian, S.., 2006, Sara, ed. cit., p. 144

20. Ibidem, p. 145

21. Ibidem, p. 69 
însă ambele realizări trec prin resemantizări marcante față de echivalentul lor din Cartea lui Tobit. Chiar și atunci cînd hipertextul aduce în centrul atenției personaje noi, fără trecut hipotextual, cum ar fi baronul Casimir Spurck, acestea constituie fertile pretexte prin care sunt problematizate noțiuni fundamentale, cum ar fi viața și moartea. $\mathrm{Nu}$ în ultimul rînd, însuşi statutul hipotextual al personajelor ,importate” este problematizat, căci proza lui Ștefan Agopian are o vădită dimensiune metatextuală. Toate acestea constituie atribute majore ale originalității ale acestui prozator contemporan. 


\section{BIBLIOGRAFIE:}

Agopian, S,., Sara, Iași, Editura Polirom, 2006.

Agopian, S,., Tobit, Iași, Editura Polirom, 2014.

Agopian, Ș., „Spre o gramatică liberală”, în Crăciun, Gh., Competiția continuă-Generația '80 în texte teoretice, Pitești, Editura Vlasie, 1994.

Constantinescu, M., "Între figură și ficțiune", România literară, nr. 5, 2004.

Genette, G., Palimpsestes: La litérature au second degré,Paris, Éditions du Seuil, 1982.

Genette, G., Palimpsests: Literature in the Second Degree, Traducere de Newman, Ch., Nebraska, University of Nebraska Press, 1997.

Genette, G., Metalepse. De la figure à la fiction, Paris, Éditions du Seuil, 2004.

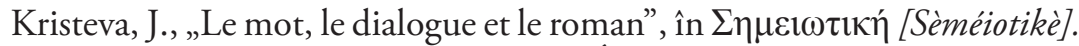
Recherches pour une sémanalyse, Paris, Éditions du Seuil, Paris, 1969.

Kristeva, J., "Word, Dialogue, and Novel”, în Desire in Language - a Semiotic Approach to Literature and Art, Traducere de Gora, Th., New York, Columbia University Press, 1980.

Mușat, C., Frumoasa necunoscută, Iași, Editura Polirom, 2017.

Riffaterre, M., apud Genette, G., Palimpsests, Nebraska, University of Nebraska Press, 1997.

Buciu, M. V., Zece prozatori exemplari, București, Editura EuroPress Group, 2007.

Holban, I., Profiluri epice contemporane, București, Editura Cartea Românească, București, 1987.

Ivăncescu, R., Ștefan Agopian: monografie, București, Editura Aula, 2000. Manolescu, N., România literară, nr. 23, 1983.

Mușat, C., Perspective asupra romanului românesc postmodern și alte ficțiuni teoretice, Pitești, Editura Paralela 45, 1998.

Negrici, E., „Prefață”, în Agopian, Ș., Tache de catifea (ediția a II-a), București, Editura 100+1 Gramar, , 1999.

Spiridon, M., „Agopian, Ștefan”, în Simion, E. (coord.), Dicționarul literaturii române, Editura Univers Enciclopedic Gold, București, 2012.

T,eposu, R. G., Istoria tragică \& grotescă a întunecatului deceniu literar nouă, București, Editura Eminescu, 1993.

Ursa, M., Optzecismul și promisiunile postmodernismului, Pitești, Editura Paralela 45, 1999. 